Rev. Leszek MISIARCZYK*

\title{
THE MISSING TURNING POINT. APOLOGETIC ROOTS OF THE NICENE CREED
}

As we know, the person of the Emperor Constantine is strictly connected to the Council of Nicea and the Creed established there in 325 A.D. Even if we can agree with the statement that there was no common or unified Creed in the whole Church before and different communities had had their own creeds, nevertheless it is clear that general frame of these creeds is based on the New Testament and it was confirmed by the later Church Fathers. I am not convinced that there was a complete liberty in the first three centuries to profess whatever every Christian community wanted to profess. Nowadays it is often assumed that Nicene Creed is a kind of compromise between those who wanted to condemn Arius and those who were afraid that this new Creed would be too similar to the heretic opinions of Paul from Samosata ${ }^{1}$. From theological point of view the fundamental question is the following one: $\mathrm{Ni}$ cene Creed only has put together and unified a different or local professions of faith existing earlier in Christian communities or has introduced a new elements? The strong resistance among many bishops to accept the Creed established during the Council and many local synods convoked after it seems to confirm that at least by the part of the Church hierarchy of that time this Creed was seen as completely new formulation and a kind of theological turning point, especially because of using three new theological expressions regarding the Son of God: "begotten not made", "begotten from the substance of the Father" and "consubstantial to the Father". Eusebius of Caesarea in his Letter to the people of his Diocese about the Creed of Nicaea, transmitted to our times by Socrates in his History of the Church, informs us that there was a lot of discussion regarding these three elements of Nicene Creed: "of the essence

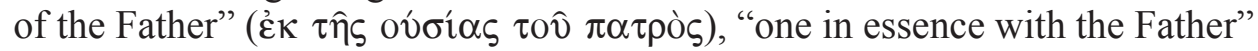

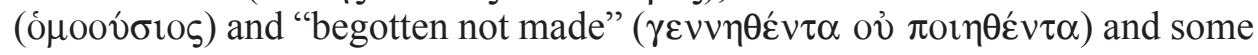

*Rev. dr. hab. Leszek Misiarczyk - Associate Professor at the Institute of History at the Faculty of History and Social Sciences of the Card. Stefan Wyszyński University in Warsaw; e-mail: 1.misiarczyk@uksw.edu.pl.

${ }^{1}$ Cf. H. Pietras - A. Baron, Wprowadzenie, in: Dokumenty Soborów Powszechnych. Tekst grecki, taciński i polski, t. 1 (= DSP), Kraków 2001, 21-23 (Introduction to the edition of Greek and Latin texts of ancient councils with Polish translation). 
bishops did not subscribe it objecting to the term ópoov́otos, "of the same essence" and "begotten not made".

Often it is argued that these three elements of the Nicene Creed were so important and new that it should be considered as turning point in the theological reflection of so called Imperial Church in the time of Constantine. Is it really so? Or the Nicene Creed has just put together all that had been taught by the Fathers of the Church before it? My hypothesis is the second one and I'll try to prove it by short analysis of the earlier patristic texts. Initially, I had an idea to analyze all Greek patristic texts from the $1^{\text {st }}$ to $3^{\text {rd }}$ century, mainly Greek Apologists of the $2^{\text {nd }}$ century, Irenaeus, Clement of Alexandria and Origen but because the vastity of material I have decided to limit my research only to the texts in Greek of the $1^{\text {st }}$ and $2^{\text {nd }}$ century.

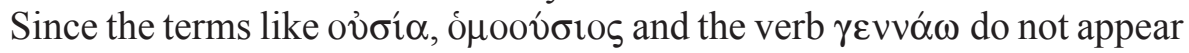
at all in the writings of so called Apostolic Fathers ${ }^{3}$, the first early Christian texts which should be taken into consideration are those of Greek Apologists of the $2^{\text {nd }}$ century: Justin Martyr's 1 and 2 Apologia and Dialogus cum Tryphone Iudeo, Tatian's Oratio ad Graecos, Athenagoras' Libellus pro Christianis and De resurrectione, Theophilus of Antioch Ad Autolycum, Epistula ad Diognetum and Irrisio of Hermias ${ }^{4}$. And because the Greek Apologists do not use at all the term ó $\mu$ oov́rı (consubstantial) ${ }^{5}$, I shall concentrate my analysis only on these two elements: "begotten not made" ( $\gamma \varepsilon v \nu \eta \theta \varepsilon \dot{\varepsilon} v \alpha$ ov $\pi \circ \eta \eta \theta \dot{\varepsilon} \nu \tau \alpha)$ and "begotten of the substance of the Father" ( $\gamma \varepsilon v \nu \eta \theta \dot{\varepsilon} v \tau \alpha \dot{\varepsilon} \kappa \tau \hat{\eta} \varsigma$

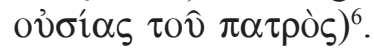

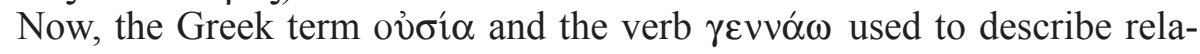
tionship between the Son and the Father appears only in the texts of Justin Martyr and Tatian. In Athenagoras' Plea for the Christians the term ovं $\sigma$ í (essence/substance) can be found 7 times but it conveys very different meanings. In two fragments: 5, 1 and 22, 1 he quotes opinion of Euripides and stoic philosophers who used ovंoí $\alpha$ to express the essence/substance of pagan divinity but it has never been referred to the relationship between the Son and

${ }^{2}$ Eusebius Caesariensis, Epistula ad Caesarienses 9-12, in: Socrates Scholasticus, HE I 8, 4650, ed. G.Ch. Hansen, GCS NF 1, Berlin 1995, 25-26; transl. P. Schaff - H. Wace, Nicene and Post-Nicene Fathers, Ser. II, vol. 2, Grand Rapids 1893, 39-43.

${ }^{3}$ Cf. E. Goodspeed, Index Patristicus sive Clavis Patrum Apostolicorum operum, Peabody 1993.

${ }^{4}$ The Latin apologists' texts of the II century will be omitted because their influence on the Nicean Creed is rather dubious.

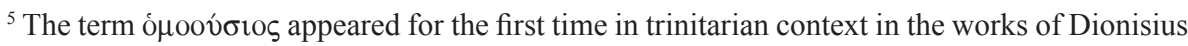
of Alexandria and later in the Synod of Antiochia in 268 as an opinion of Paul of Samosata - see W.A. Bienert, Das vornicaenische homoousios als Ausdruck der Rechtgläubigkeit, ZKG 90 (1979) 151-175; G.C. Stead, Divine substance, Oxford 1977, 199ff; P.F. Beatrice, The Word "homoousios" from Hellenism to Christianity, ChH 71 (2002) 243-272; M. Simonetti, Homoousios, DPAC II 2498-2499.

${ }^{6}$ Cf. E. Goodspeed, Index Apologeticus, Leipzig 1912. 
the Father in a Christian sense ${ }^{7}$. Even if there is no reference to the Christian context in his work, Athenagoras, however, is very useful to discover the origin of Christian use of the term ov̉oí $\alpha$. If it was used in Greek philosophical literature to describe the essence of pagan divinities, so it is quite probable that the Greek term ovo'i $\alpha$, since it appears for the first time in the works of Greek Apologists, was taken from Greek philosophical literature and adopted to describe also the substance of $\mathrm{God}^{8}$. Now let's concentrate our research on

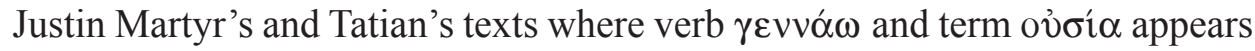
for the first time in a Christian sense.

1. Justin Martyr. Justin Martyr is one of the most important Christian Apologists of the 2 nd century who lived between 100 and 165 A.D. ${ }^{9}$ According to Eusebius he wrote 8 works but only three of them, that is 1 and 2 Apo$\log y^{10}$ and Dialogue with Trypho, the Jew ${ }^{11}$ survived to our time. The reference to our theme is spread throughout all of Justin's texts so now let's analyze the fragments important for our research.

In 1 Apology 12, 7 Justin, after having criticized persecution of Christians by Roman Emperors, makes this statement:

"And that you will not succeed (to eliminate the Christians - underl. mine L.M.) is declared by the Word, than whom, after God who begot Him ( $\mu \varepsilon \tau \grave{\alpha}$ $\tau$ òv $\gamma \varepsilon v v \eta \dot{\sigma} \sigma \alpha \nu \tau \alpha \Theta \varepsilon \hat{v} v)$, we know there is no ruler more kingly and just"12.

As it can be easily noticed Justin expresses the birth of the Logos from God

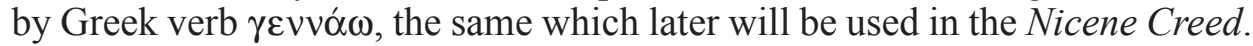
The context of this affirmation clearly indicates that he had in mind spiritual generation of Logos from God and not simply human generation. The Logos after ( $\mu \varepsilon \tau \grave{\alpha})$ the generation from God is the unique king, ruler and just ${ }^{13}$. This

${ }^{7}$ Cf. D. Powell, Athenagoras and the Philosophers, "Church Quarterly Review" 168 (1961) 282-289; A.J. Malherbe, Athenagoras on the pagan poets and philosophers, in: Kyriakon. Festschrift J. Quasten, ed. P. Granfield - J.A. Jungmann, Bd. 1, Münster 1970, 214-225.

${ }^{8}$ Cf. G.C. Stead, The Concept of Divine Substance, VetCh 29 (1975) 1-14; idem, Divine Substance, Oxford 1977.

${ }^{9}$ Cf. L.W. Bernard, Justin Martyr. His life and Thought, London - New York 1967; E. Goodenough, The Theology of Justin Martyr, Amsterdam 1968.

${ }^{10}$ The new edition of the Greek text has been prepared by ed. M. Marcovich: Iustini Martyris. Apologiae pro Christianis, Patristische Texte und Studien 38 (= PTS), Berlin - New York 1994. See also Ch. Munier, Introduction, in: Saint Justin, Apologie pur les Chrétiennes. Éditions et traduction, Fribourg 1995, 10ff.; P. Keresztes, The literary genre of Justin's First Apology, VetCh 19 (1965) 99100; idem, The so-called Second Apology, "Latomus" 24 (1965) 858-869.

${ }^{11}$ See the new edition (by M. Marcovich) of the text: Iustini Martyris. Dialogus cum Tryphone, PTS 47, Berlin - New York 1997.

${ }^{12}$ Iustinus Martyr, Apologia I 12, 7, PTS 38, 49, transl. A. Roberts - J. Donaldson, in: Ante-Nicene Greek Fathers, vol. 1, Grand Rapids 1981, 166.

${ }^{13}$ Cf. G. Aeby, Les missions divines de S. Justin à Origèn, Freiburg 1958, 22-34; Goodenough, 
is fundamental reason why Romans will not be able to eliminate all Christians from the world because their faith is based upon divine Logos ${ }^{14}$.

In 1 Apology 22, 2 Justin is convinced that even if Jesus were only a man by ordinary generation, yet, on account of His wisdom, deserves to be called the Son of God; for all writers call God the Father of men and gods. And later he adds:

"And if we assert that the Word of God was born of God in a peculiar manner, different from ordinary generation ( $\pi \alpha \rho \grave{\alpha} \tau \grave{\eta} v$ Kolvìv $\gamma \varepsilon \dot{\varepsilon} v \varepsilon \sigma v v, \gamma \varepsilon \gamma \varepsilon v v \hat{\eta} \sigma \theta \alpha \imath$

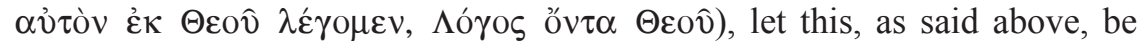
no extraordinary thing to you, who say that Mercury is the angelic word of God"15.

The sense of this fragment, however, is not entirely clear: it refers to the human or divine generation? In the beginning of the chapter 22 Justin talks about Jesus' human existence who thanks to His wisdom could be called a Son of

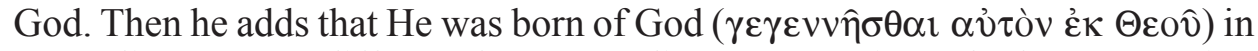
a peculiar manner, different from an ordinary generation. The last expression

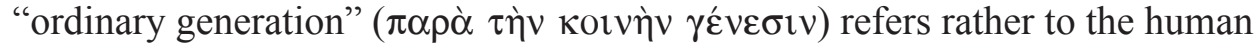
generation of Jesus who, even as a man would have been born in a peculiar manner by the extraordinary intervention of God and not through normal sexual relation between man and woman. So the text would refer rather to the extraordinary but still a human generation of Jesus.

The third fragment regarding our issue can be found also in 1 Apology a little bit later in chapter 23, 2:

"That Jesus Christ is the only proper Son who has been begotten by God,

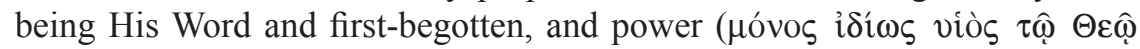

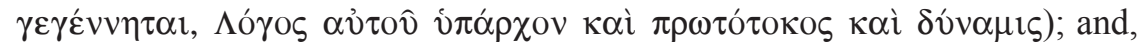
becoming man according to His will, He taught us these things for the conversion and restoration of the human race" 16 .

In this fragment Justin calls Jesus the only proper Son ( $\mu$ óvos idíws viòs),

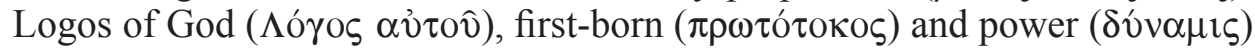
and all these terms indicate clearly His condition as a divine being and not

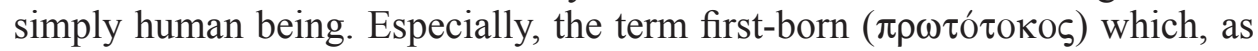
we know, comes from the Letter of St. Paul to the Colossians 1, 15 describes the birth of the Son from God before all creatures. Of course, we know that in the future the term first-born ( $\pi \rho \omega \tau$ tó

The Theology of Justin Martyr, p. 139-174; M. Edwards, Justin's Logos and the Word of God, JECS 3 (1995) 261-280.

${ }^{14}$ Cf. P. Kerszets, Law and Arbitrariness in the Persecution of Christians and Justin's First Apology, VetCh 19 (1965) 2-44-214.

${ }^{15}$ Iustinus Martyr, Apologia I 22, 2, PTS 38, 65, transl. Roberts - Donaldson, p. 170.

${ }^{16}$ Ibidem 23, 2, PTS 38, 65, transl. Roberts - Donaldson, p. 170. 
from God became for Arius and other theologians a good reason to exclude the divinity of the Son of God. They thought that if He has been begotten it means He had not existed before and he started to be in the time then He is not equal to God and cannot be called a real Son of God. Justin did not have any problem to use these expressions to describe the status of Christ, the Son of God because the danger of Arianism was still far away. He did not take at all into consideration the question of the beginning but simply wanted to say that relationship between the Son and God the Father should be described in terms of generation by the verb $\gamma \varepsilon \gamma \varepsilon \dot{\varepsilon} v \nu \eta \tau \alpha$. And because God is a spirit so this generation should be seen as a spiritual generation. Once again then we find a clear

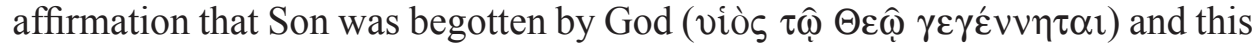
generation is a spiritual one and refers to the divine generation before all ages.

In 2 Apology 6, 1 Justin affirms that "the Father of all is unbegotten" ( $\pi \alpha \tau \dot{\varepsilon} \rho$

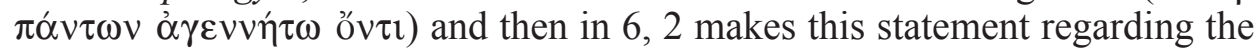
Son of God and Logos:

"And His Son, who alone is properly called Son, the Word, who also was with Him and was begotten before the works, when at first He created and arranged all things by Him, is called Christ, in reference to His being anointed and God's ordering all things through Him"17.

The text contains a few interesting elements. Logos is presented here as a Son

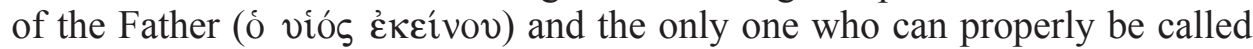
Son of God (ó $\mu$ óvoৎ $\lambda \varepsilon \gamma o ́ \mu \varepsilon v o \zeta ~ \kappa v p i ́ \omega \varsigma$ viós). Justin clearly indicates that the status of Jesus Christ as the Son of God is totally different then the status of any human being even if considered a son of God but always in an improper way. In other words, the sonship of Jesus, the Son of God is of the completely different character then the sonship of all other men. Only he is the true Son of God and Logos who existed with God before all things and was begotten (ò $\Lambda$ ó $\gamma \circ \varsigma$

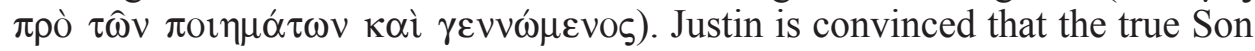
of God and Logos of God had existed before the world was created and had been begotten also before all things were created. Justin does not speak about generatio ab aeterno as it will be done in later Christian texts but this fragment is the first Christian text which clearly affirms that the Son of God was begotten before the creation of the world, that is before time was created. And this generation is once again described by Greek verb $\gamma \varepsilon v v \omega ́ \mu \varepsilon v o s$. I would like to underline strongly these two elements because very often it is wrongly said that in Greek Apologists of the 2nd century we do not find any confirmation of eternal existence of the Logos. Now, this fragment from 2 Apology 6, 2 clearly

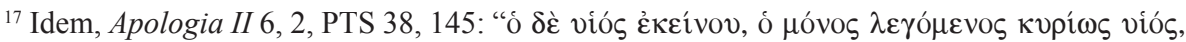

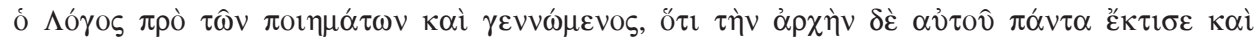

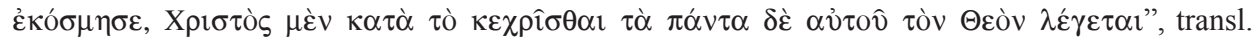
Roberts - Donaldson, p. 190. 
contradict a such opinion. Justin does not use, of course, the term "eternal generation" but speaking about generation of the Logos before the world and time were created he indirectly sees this generation as out of time ${ }^{18}$.

Another Justin's work preserved to our times is, as we know, Dialogue with Trypho the Jew. The first fragment of Dialogue where the reference to the generation of Jesus Christ appears is Dialogue 54, 2 in which the author explains the meaning of the prophecy in Gen 49, 11:

"And that expression which was committed to writing by Moses, and prophesied by the patriarch Jacob, namely, «He shall wash His garments with wine, and His vesture with the blood of the grape» [...] the Scripture mentions the blood of the grape was evidently designed, because Christ derives blood not from the seed of man, but from the power of God. For as God, and not man, has produced the blood of the vine, so also [the Scripture] predicted that the blood of Christ would not be of the seed of man, but of the power of God. But this prophecy, Sirs, which I repeated, proves that Christ is not a man of men,

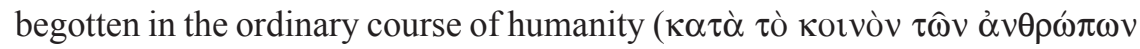

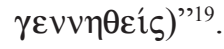

The term generation ( $\gamma \varepsilon v v \eta \theta \varepsilon i \varsigma)$ is mentioned in this text but it clearly is referred to the human birth of Jesus Christ.

The second fragment is the one we find in Dialogue 61, 1:

"I shall give you another testimony, my friends, said I, from the Scriptures, that God begat before all creatures a Beginning, [who was] a certain ratio-

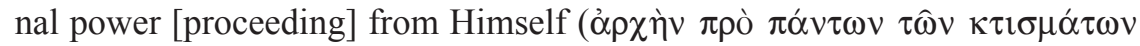

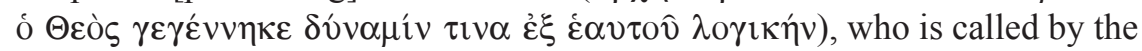
Holy Spirit, now the Glory of the Lord, now the Son (viòs), again Wisdom

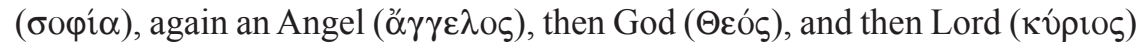
and Logos ( $\lambda$ ó $\gamma \circ \varsigma)$; and on another occasion He calls Himself Captain, when He appeared in human form to Joshua the son of Nave (Nun). For He can be called by all those names, since He ministers to the Father's will, and since $\mathrm{He}$

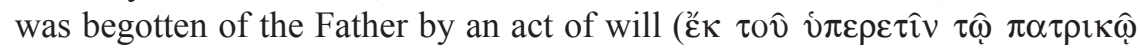

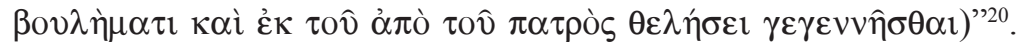

Now let's look closer at some elements of this fragment. Justin has the intention to give his interlocutors another testimony from the Scripture that God

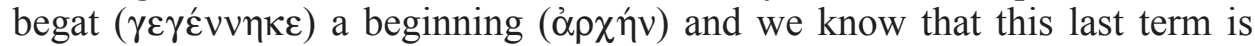

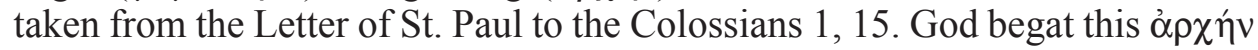
before having created all creatures. Let's note also the difference: Justin uses

\footnotetext{
${ }^{18}$ Cf. Edwards, Justin's Logos and the Word of God, p. 261-280.

${ }^{19}$ Iustinus Martyr, Dialogus cum Tryphone Iudeo 54, 2, PTS 47, 159, transl. Roberts - Donaldson, p. 214

${ }^{20}$ Ibidem 61, 1, PTS 47, 174-175, transl. Roberts - Donaldson, p. 227.
} 
the Greek verb $\kappa \tau i \zeta \omega$ to describe creation of all creatures and the generation of "a certain rational power from Himself" expresses with the verb $\gamma \varepsilon v v \alpha \dot{\omega} \omega$. The

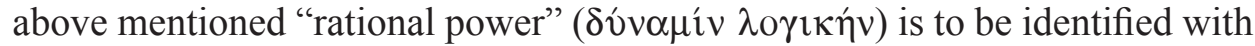
the Son of God, Wisdom, the Messenger of God (Angel), God, Lord, Logos and the Chief Commander who appeared in human form to Joshua. He can

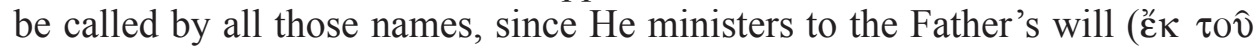

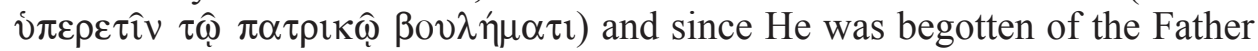

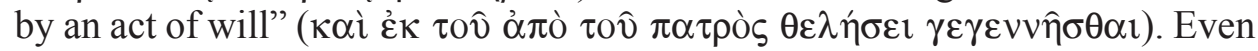
if we can see the difference Justin uses to describe the service of this rational power to the Father's will with Greek term $\beta$ ov $\lambda \eta \mu \alpha$ and His being begotten of the Father by an act of will with Greek $\theta \varepsilon \lambda \eta \mu \alpha$, it does not change a lot. General sense of this fragment is that the rational power begotten from the Father before the material world was created is identical with the Glory of God, the Son of God, Wisdom, the Messenger of God (Angel), God, Lord, Logos and the Chief Commander who appeared to Joshua. He has been begotten, however, not from the substance of the Father but by the act of His will ( $\tau$ o $\hat{\jmath} \alpha$ ò

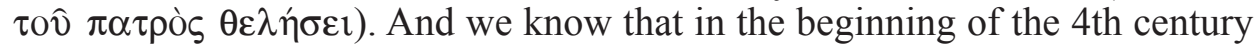
Arius will declare the same affirming that the Son of God has been begotten only from the will of the Father and not from His substance and he cannot be called a real Son of God equal to Him in the nature. Justin, however, cannot be seen in any way as a forerunner of Arius. He explains the sense of this generation in Dialogue 61, 2

"Just as we see happening among ourselves: for when we give out some

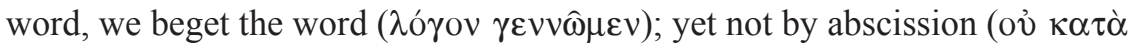

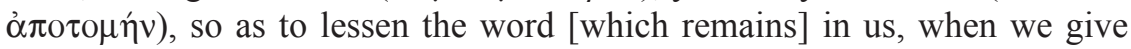
it out: and just as we see also happening in the case of a fire, which is not lessened when it has kindled [another], but remains the same; and that which has been kindled by it likewise appears to exist by itself, not diminishing that from which it was kindled"21.

Justin and after him many other early Christian writers will use this metaphor to explain the generation of the Son from the Father. Just as we beget word yet not by the abscission so as to lessen the word which remains in us or as we see happening in the case of fire which is not lessend when it kindled another, in the same way the substance of the Father is not diminished when He generates the Son but remains the same.

In Dialogue 61, 3 he still develops his argumentation on the same subject adding also some new elements:

"The Word of Wisdom, who is Himself this God begotten of the Father of all things, and Word, and Wisdom, and Power, and the Glory of the Begetter,

${ }^{21}$ Ibidem 61, 2, PTS 47, 175, transl. Roberts - Donaldson, p. 227. 
will bear evidence to me, when He speaks by Solomon the following: Prov $8,21-36^{\prime \prime 22}$.

In this fragment we find once again very strong affirmation that Logos,

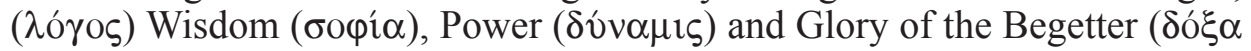

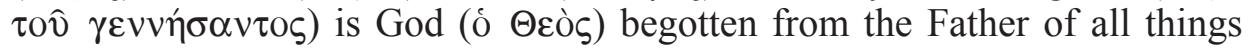

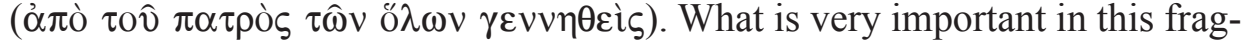
ment is the fact that Justin clearly identifies Logos with God begotten from God, the Father of all things.

Next fragment of the Dialogue important for our analysis is 62,4 where we find subsequent explanation:

"But this Offspring, which was truly brought forth from the Father, was with the Father before all the creatures, and the Father communed with Him ( $\dot{\alpha} \lambda \lambda \dot{\alpha}$

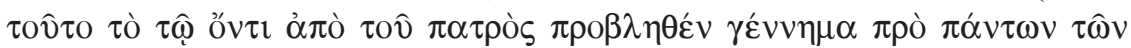
$\pi \mathrm{o} \eta \mu \alpha \dot{\alpha} \tau \omega \nu \sigma v v \hat{\eta} v \tau \hat{\omega} \pi \alpha \tau \rho i$ ); even as the Scripture by Solomon has made clear, that He whom Solomon calls Wisdom, was begotten as a Beginning

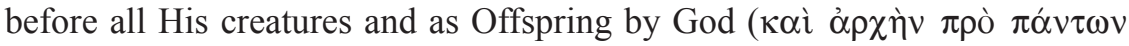

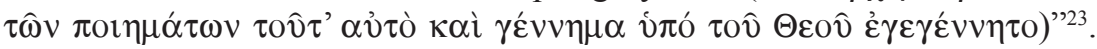

Three elements in this text are important for our research. Once again Justin confirms that the Son called here "Offspring by God" was brought forth from

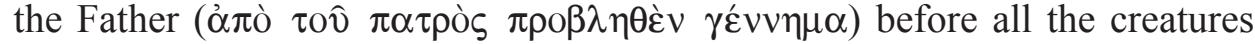

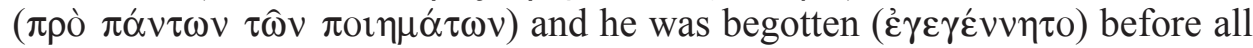

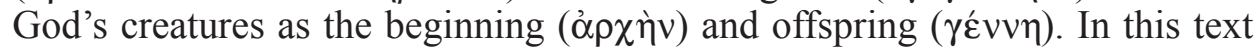
Justin does not mention at all if He was begotten form the substance of the Father or His will.

In Dialogue 76, 7 Justin once again tries to convince his interlocutors to Jesus Christ according to the prophecy of Psalms 110, 3 and 72, 5. 17 which is here clearly a Christian testimonium based on Old Testament texts:

"David predicted that He would be born from the womb before sun and

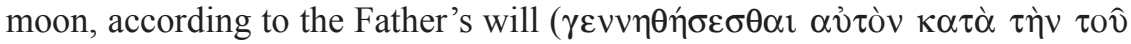

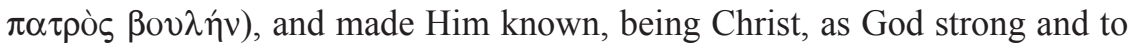
be worshipped"24.

Justin repeats here once again two elements important for our research: Christ, the Son of God was born ( $\gamma \varepsilon v \nu \eta \theta \eta \tilde{\sigma} \sigma \sigma \theta \alpha \mathrm{l})$ from the Father and according to

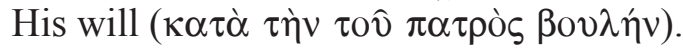

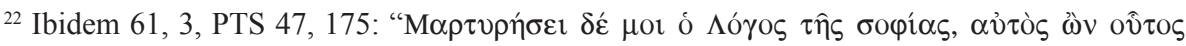

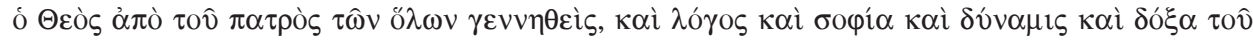

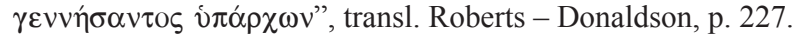

${ }^{23}$ Ibidem 62, 4, PTS 47, 177, transl. Roberts - Donaldson, p. 228.

${ }^{24}$ Ibidem 76, 7, PTS 47, 202, transl. Roberts - Donaldson, p. 237. 
The most important testimony on our issue can be found in Justin's Dialogue 128, 4. Even if the fragment is quite long, it merits to be quoted as a whole:

"And that this power which the prophetic word calls God, as has been also amply demonstrated, and Angel, is not numbered [as different] in name only like the light of the sun but is indeed something numerically distinct ( $\dot{\alpha} \lambda \lambda \dot{\alpha}$

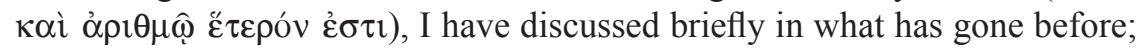
when I asserted that this power was begotten from the Father, by His power and will, but not by abscission, as if the essence of the Father were divided

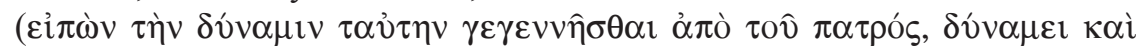

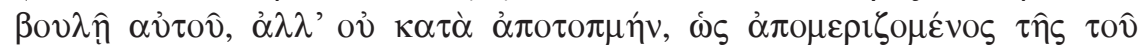
$\pi \alpha \tau \rho o ́ \varsigma$ ovं $\left.\sigma^{\prime} \alpha \varsigma\right)$; as all other things partitioned and divided are not the same after as before they were divided: and, for the sake of example, I took the case of fires kindled from a fire, which we see to be distinct from it, and yet that from which many can be kindled is by no means made less, but remains the same"25.

Four points merit to be called to mind in this fragment. First, Justin clearly affirms that Logos is called by prophetic word God and is numerically really distinct from God the Father and not just having a different name. The difference means real difference of being and not only a nominal difference.

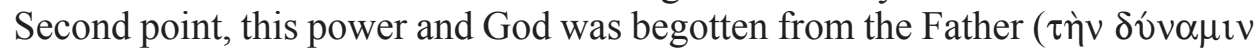

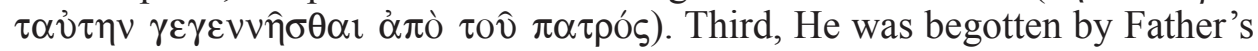

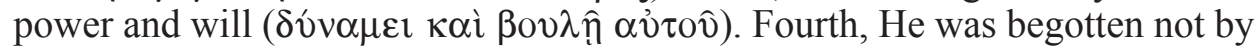

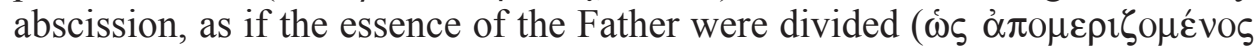

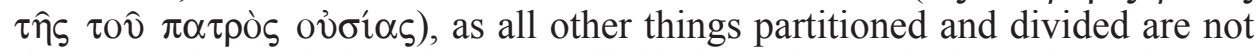
the same after as before they were divided. Justin speaks here about the Son being begotten from the Father by His power and will but also indirectly form His substance. This generation cannot be understood as if the substance of the Father would have been divided or did not remain the same after generation of the Son. This text of Dialogue is, at my knowledge, the first patristic text where there is mentioned for the first time in early Christian literature the term of "the substance of the Father" and the generation of the Son from this substance. Not only that, but also Justin strongly defends the integrity of this substance of the Father after the generation of the Son. To explain better this spiritual and out of time generation Justin adopts the image of the fire kindled from another fire, which is distinct from it, and yet by no means loose its nature, but remains the same. As we know this image will be used later in the Church creeds to describe the eternal generation of the Son from the Father ${ }^{26}$.

\footnotetext{
${ }^{25}$ Ibidem 128,4, PTS 47, 293, transl. Roberts - Donaldson, p. 264.

${ }^{26} \mathrm{Cf}$. Goodenough, The Theology of Justin Martyr, 156ff.
} 
And finally the last of Justin's texts which speaks about the generation of the Logos and the Son is Dialogue 129, 3-4:

"You perceive, my hearers, if you bestow attention, that the Scripture has declared that this Offspring was begotten by the Father before all things created; and that which is begotten is numerically distinct from that which be-

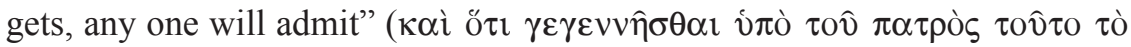

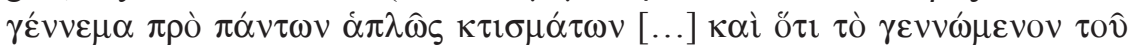

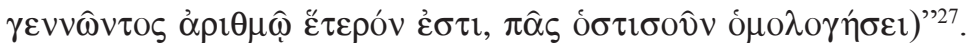

Justin once again repeats that this Offspring was begotten by the Father before

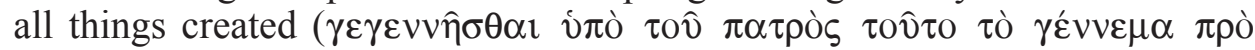
$\pi \dot{\alpha} v \tau \omega \nu \dot{\alpha} \pi \lambda \hat{\omega} \varsigma \kappa \tau \imath \sigma \mu \alpha \dot{\alpha} \tau \omega v)$ and He is numerically distinct from that which

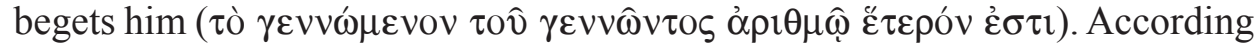
to him this generation of the Son from the Father is a real generation giving existence to One who is numerically different and not only by name but He still has the same substance as the Father. Justin does not distinguish yet between substance and person which will be typical of theological discussions in 3rd and 4th century but expresses the identity of Son and Father underlying that both have the same undivided substance and the personal difference between them is seen as a numerical distinction not merely nominal.

2. Tatian. Tatian, the Syrian is the second important Christian Greek Apologists of the second century who evoked the question of Logos' generation in his unique work which reached our time Address to the Greeks ${ }^{28}$. In this text we find only two fragments in which Tatian presents his thought about generation of the Logos from the Father. The first one is from Oratio ad Graecos 5, 2-4:

"And by His simple will the Logos springs forth; and the Logos, not coming forth in vain, becomes the first-begotten work of the Father. Him [the Logos] we know to be the beginning of the world. But He came into being by participation, not by abscission; for what is cut off is separated from the all original, but that which comes by participation, making its choice of function, does not render him deficient from whom it is taken. For just as from one torch many fires are lighted, but the light of the first torch is not lessened by the kindling of many torches, so the Logos, coming forth from the Logos-power of the Father, has not divested of the Logos-power Him who begat Him"29.

${ }^{27}$ Iustinus Martyr, Dialogus cum Tryphone Iudeo 129, 3-4, PTS 47, 294, transl. Roberts - Donaldson, p. 264.

${ }^{28}$ See the new edition of the Greek text ed. M. Marcovich, Tatiani Oratio Ad Graecos, PTS 43, Berlin - New York 1995 and studies M. Elze, Tatian und seine Theologie, Göttingen 1960; G.F. Hawthorne, Tatians and his Discourse to the Greeks, HTR 57 (1964) 161-188; F. Bolgiani, Taziano, NDPAC II 5205-5209.

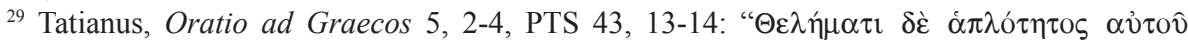


Logos came to existence by an act of Fathers' will and became the first-begot-

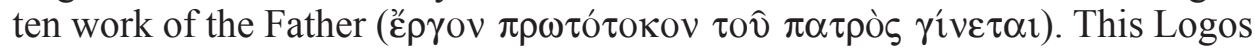

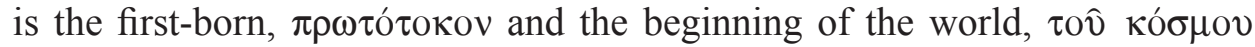

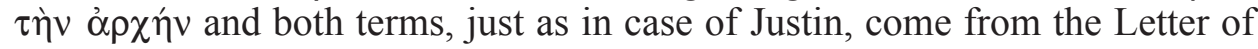
St. Paul to the Colossians 1, 15. But while Justin has only affirmed that this

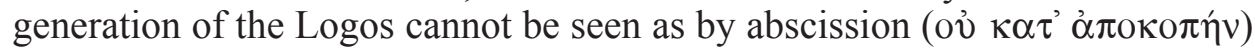
and Tatian repeats the same, he adds also that the Logos came out into being by participation ( $\kappa \alpha \tau \grave{\alpha} \mu \varepsilon \rho \imath \sigma \theta \varepsilon \dot{\varepsilon} v$ ). Tatian refuses then either the category of abscission or cutting off either complete separation between Son and Father but prefers the category of participation which, in his opinion, saves at the same time the difference between the Logos and the Father and their common existence. Thus, the Son coming out by participation, makes its choice of function and does not render the Father deficient. Then Tatian comes back to the same image we have already seen in Justin's Dialogue with Trypho: like a torch lights many fires and its light is not lessened by the kindling of many torches, so the Logos, coming forth from the Logos-power of the Father, has not divested of the Logos-power in Him who begat Him. Tatian like Theophilus of Antioch in his Ad Autolycum distinguishes between Logos external and Logos internal who came out as an instrument by whom God created the world. This internal Logos can be considered as a kind of divine nature of God the Father in which the Son still participates even after his being born from Him. Tatian wants to say: the fact of having begotten Logos did not deprive God the Father of His rationality and did not make Him ö $\lambda$ orov. And the Logos was begotten

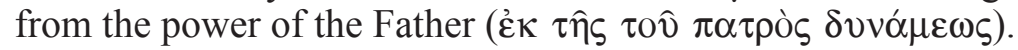

The second and last fragment is found in the same work of Tatian Oratio Ad Graecos 7, 1:

"For the heavenly Logos, a spirit emanating from the Father and a Logos from the rational power, in imitation of the Father who begat Him"30.

Logos is seen here as a spirit $(\pi v \varepsilon \hat{v} \mu \alpha)$ who has emanated from the spirit

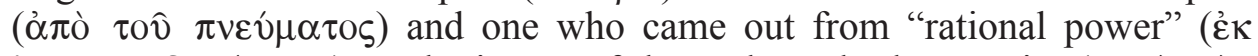

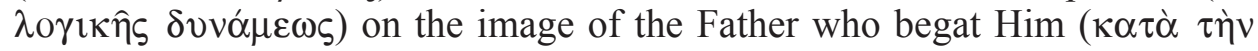

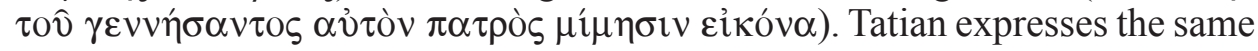

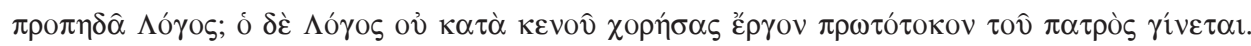

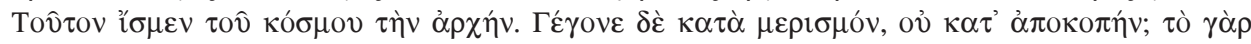

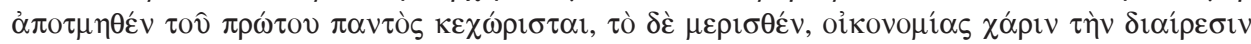

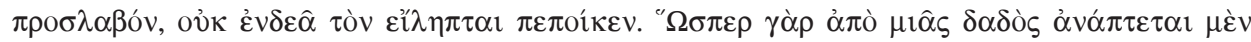

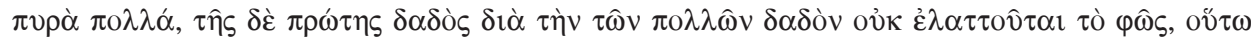

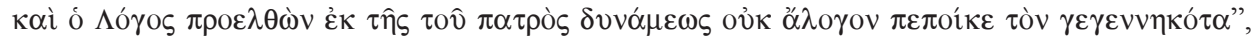
transl. A. Roberts - J. Donaldson, Ante-Nicene Greek Fathers, vol. 2, Grand Rapids 1981, 67.

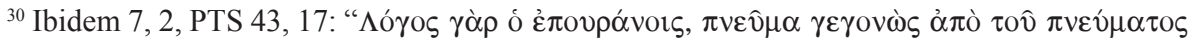

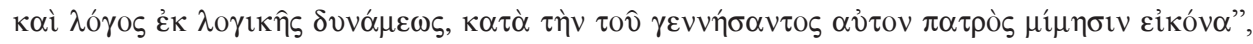
transl. Roberts - Donaldson, p. 67.
} 
spiritual nature of the Father and the Son by the term $\pi v \varepsilon \hat{v} \mu \alpha$ and the pro-

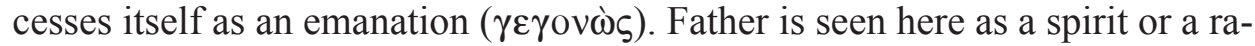
tional power from whom Logos has been generated. So once again the Father is the one who begat the Logos.

1. In all above mentioned texts it is said that Logos identified with the Glory of God, the Son of God, Wisdom, God, Angel (Messenger) and Chief Commander was begotten from the Father.

2. Justin and Tatian never use the Greek verb $\kappa \tau i \zeta \omega$ (to create) to describe

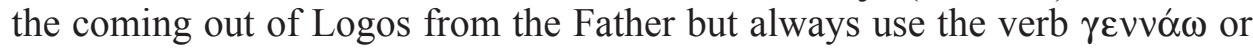
the noun $\gamma \dot{v} v v \varepsilon \sigma i s$.

3. Justin speaks about two kinds of generation of the Son: one, spiritual from the Father "before all creatures/things" or before the material world was created and the second one from the Virgin in the specific time. Even if he never uses the term "eternal generation", this first generation can be understood as having place before the material world and the time were created so in some way out of time.

4. In a few fragments the Logos/Son of God is said to be begotten "of the

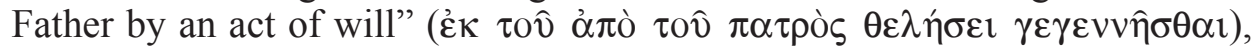

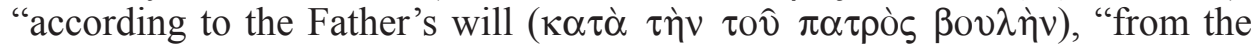

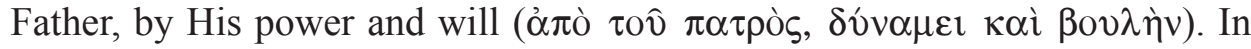
Dialogue 128, 4, even if Justin does not use expression "was begotten form the substance of the Father" but saying "He was begotten not by abscission, as if

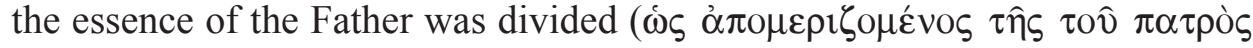

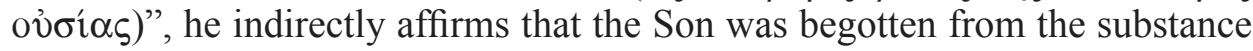
of the Father. Dialogue 128, 4 is also the first Christian text where the term

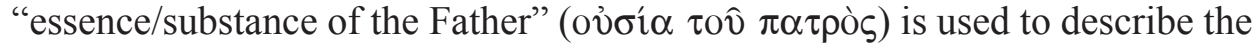
nature of God.

5. The generation of the Son from the Father took place not by abscission or complete separation but by participation like a new fire lighted from the torch.

6 . As a result of this generation the Son is indeed numerically distinct from the Father. The Son is different from the Father not only by name but by a really new existence even if He still participates in the same undivided divine substance (ov̉oí $\alpha$ ).

7. At least in these two points: the Son ,was begotten from the Father" and $\mathrm{He}$,was begotten from the substance of the Father" the Nicene Creed is no way the turning point in Christian theological reflection but it only reaffirms theological concepts which were invented by Justin and Tatian already in the $2^{\text {nd }}$ century. 


\section{ZWROT, KTÓREGO NIE BYŁO. KORZENIE CREDO NIECEJSKIEGO W PISMACH APOLOGETÓW GRECKICH}

\section{(Streszczenie)}

W tekstach apologetów greckich II w. jest wyraźnie powiedziane, że Logos został zrodzony z Ojca, a Justyn i Tacjan na opisanie tego procesu używają zazwyczaj greckiego czasownika $\gamma \varepsilon v v \alpha ́ \omega$ (rodzić), nigdy zaś $\kappa \tau i \zeta \omega$ (stwarzać). Justyn Męczennik jest pierwszym autorem chrześcijańskim, który użył zwrotów „zrodzony z woli Ojca”, „według woli Ojca”, „z Ojca, Jego wolą i moca”". W Dialogu z Żydem Tryfonem 128, 4 pośrednio potwierdza on, że Syn został zrodzony z substancji Ojca i używa po raz pierwszy w tekstach chrześcijańskich terminu "substancja Ojca" (ov̉oí $\alpha$ ), aby opisać naturę Boga. Precyzuje również, że to zrodzenie Syna z Ojca dokonało się nie przez odcięcie albo całkowite oddzielenie się, ale przez uczestnictwo, podobnie jak nowy ogień zapala się od starego nie umniejszając jego natury. Ten Syn zrodzony z Ojca jest według Justyna numerycznie odrębny od Niego i różni się od Niego nie tylko imieniem, ale rzeczywistym nowym istnieniem choć nadal uczestniczy w tej samej niepodzielnej substancji. Tak więc przynajmniej w tych dwóch punktach: Syn „został zrodzony z Ojca" i "został zrodzony z substancji Ojca" Credo Nicejskie nie jest żadnym teologicznym punktem zwrotnym, a potwierdza jedynie teologiczne idee wypracowane już przez Justyna i Tacjana w II wieku.

Key words: Apologetics, Nicene Creed, Justin Martyr, Tatian.

Słowa kluczowe: Apologeci, Credo Nicejskie, Justyn Męczennik, Tacjan 
